\title{
Analysis on Application of Task-based Language Teaching Method in English Teaching of Application-oriented Universities
}

\author{
Fang Chen
}

\author{
Nanchang Institute of Science and Technology, Nanchang Jiangxi, 330000, China
}

\begin{abstract}
Key words: English teaching of application-oriented universities, Task-based language teaching, Application, Analysis.
\end{abstract}

\begin{abstract}
Since the establishment of application-oriented universities, the function of task-based language teaching has become increasingly prominent. Presently, English teachers of many universities attach certain importance to task-based language teaching. This paper aims to analyze this teaching method based on years of teaching experience of the writer, covering the situation of carrying out of task-based teaching in English teaching of application-oriented universities, and effective implementation steps and considerations, for reference.
\end{abstract}

\section{Introduction}

With the rapid social and economic development, more and more excellent talents are needed, and universities make greater efforts to train talents and explore scientific teaching modes. For English teaching of application-oriented universities, task-based language teaching is an effective way to improve the quality of teaching. Hence, researches on the application of task-based English teaching in application-oriented universities are great practical significance. Presently, task-based language teaching method is widely used in English teaching, but it is a long way to fully understand its connotation and work out effective implementation methods. Therefore, teachers should pay attention to it.

\section{Practical Significance of Application of Task-based Language Teaching Method in Classroom Teaching}

In the process of task-based teaching, people play an essential role. Teachers are needed to dominate and help students to complete language application activities, to ensure that students can learn and understand language better ${ }^{[1]}$. The reasons for carrying out task-based language teaching in English teaching of application-oriented universities are follow. Firstly, the reform of learning method mainly relates to ideas in the process of course reform, and the actual learning process of students should be especially emphasized. Nevertheless, in the process of task-based language teaching, learning process should be especially stressed. Thus, it is imperative to carry out task-based language teaching. Secondly, under the new course standards, new teaching ideas should be promoted, and task-based language teaching exactly meet this requirement. Besides, it is also a new form in the long-term development process of teaching. Thus, this is another point that is widely promoted.

\section{Explanation of English Teaching of Application-oriented Universities and Task-based Language Teaching}

Application-oriented universities mainly refer to universities positioned to be application-oriented type rather than research-based type or other types, which are founded to serve local economy, meet the need of high-level application-oriented talents and promote the popularization of higher education. 
English is a key part of courses of application-oriented universities. Therefore, to actively promote English teaching, problems should be considered based on the teaching objectives of application-oriented universities and from a developing perspective. Only in this way, an optimal objective of talent training can be worked out.

Task-based teaching always play an important role in application-oriented English teaching. It is a new teaching mode. Specifically, it refers to that under the guidance of teachers, students tackle learning tasks by means of experience, cooperation and practice, and then feel the joy of success. In actual teaching process, stress should be laid on students, and the conventional teaching mode should be changed. Thus, students act as the teaching subject, and teachers play a dominant role to guide students to take part in teaching activities, help students to learn and master knowledge and truly understand knowledge essence in the process of application by assigning teaching tasks ${ }^{[2]}$. In task-based teaching mode, more importance is paid to the process of teaching, and students change the conventional learning method, so that more ideal teaching effect is achieved. This has positive effect on course reform and teaching quality improvement.

\section{Principle of Applying Task-based Language Teaching Method in English Teaching of Application-oriented Universities}

Concerning task-based language teaching, the most important thing is to plan and organize teaching based on tasks, take learning as a process of task fulfillment, and organically combine tasks with course objectives. Hence, in the process of applying task-based language teaching method, the most important precondition is to ensure the perfectness of task design. English teachers should master the method of task design, and define tasks and types. Besides, related principles should be observed when the understanding of this teaching method and process is deepened.

\section{Student-centered Principle}

In the idea of task-based language teaching, learners are considered as the center, importance is attached to the dominant role of learners in knowledge construction, and attention is paid to positive effect of learners' experience on their learning. From the essence of learning, students should acquire knowledge as far as possible. For participants in education activities, students must hold the central position in the process of task-based teaching.

\section{Principle of Coherence and Cohesion}

Task-based teaching specifically refers to fulfilling teaching objectives based on a group or a series of tasks $^{[3]}$. In task-based language teaching, it should be guaranteed that the tasks or sub-tasks under a task in the course are always associated with each other, conform to a unified teaching objective, and completely cohere with each other in respect of content.

\section{Authenticity Principle}

In the process of task design, it must be ensured that learners are provided with accurate and true language information, and language form and situations should comply with functions and laws, so that learners can understand and master language application naturally. The authenticity of task-based language teaching requires to take information from real life as far as possible, and create situations of task fulfillment or activities in line with real life as far as possible. For task design, situations close to real environment should be created as far as possible to provide students with chances of contacting and processing real language information, and ensure students can apply language and related skills in classroom learning process freely, and have a good command of language in real life.

\section{Operability Principle}

English teachers should pay attention to the operability of tasks in classroom environment when designing tasks, try best to avoid classroom task consisting of multiple links or of complex procedures, and instruct students to get corresponding mode of task fulfillment or operation as and 
when necessary. The complexity and difficulty of tasks both will affect task fulfillment. The operability principle is directly related to task design links. Hence, full consideration must be made to guarantee overall planning is made.

\section{Principle of Combining Form with Functions}

In language practice process in the past, the most prominent problem is that language was separated from language environment and functions. Under the action of the principle of combining form with functions, the relation between language form and the actual application functions becomes clearer and clearer, and learners learn to feel the relation between language form and functions via task fulfillment and realize the relation between language and language environment. Thus, language learning can be truly reflected in real environment. As far as students are concerned, they must organically combine form with functions in the process of task fulfillment. If importance is attached to the actual use functions of language just for fulfilling tasks, then students cannot hit the point, will separate language learning from its actual application significance, and then cannot develop their ability of English application well.

\section{Related Researches on Application of Task-based Language Teaching Method in English Teaching of Application-oriented Universities}

At the present stage, task-based language teaching method is an important part of English teaching of universities. It has promoted the implementation of teaching, been recognized by English teachers, and a good application effect. With this method, teachers can select proper teaching methods based on comprehensive considerations such as course teaching contents, students' hobbies and interests and language foundation, etc.. Teachers should design teaching contents and adopt teaching methods according to considerations mentioned above, to ensure the teaching contents are popular students. Generally, the process of task-based language teaching is divided into three stages, namely pre-teaching; teaching in progress; post-teaching.

Before the implementation of task-based language teaching, good preparations should be made such as materials required for classroom teaching and teaching contents (including glossary, grammar, and sentence pattern, etc.). In general, teachers should reserve enough knowledge for implementing teaching. Hence, the most important aim of task-based teaching is to accomplish corresponding learning tasks, and the ultimate aim is to help students to master knowledge better ${ }^{[4]}$.

In the implementation process of task-based language teaching, teachers should assign learning tasks to students, give specific guidance, and try best to prevent students from deviating from learning objectives. Besides, teachers also should supervise and urge students, and take the most reasonable methods to solve problems. Teachers should guide students to actively solve problems, and offer suggestions and opinions to students on problem solving, to guarantee that students can select proper methods to solve problems.

After the implementation of task-based language teaching, a link that students present their performance in task fulfillment and make a summarization should be arranged, so that students can deepen their understanding of what they learnt, and master knowledge more deeply and widely. There are many ways to arrange students to present their performance, say, dividing students into teams, and letting students to present their performance to their team members. If the size of class is small, then it is unnecessary to divide the class for this purpose.

Through the three stages, the advantages of task-based language teaching can be put into full play, so that students can learn knowledge and skills better.

\section{Considerations in Implementation Process of Task-based Language Teaching}

In the process of English teaching of application-oriented universities, especially in the event that task-based language teaching method is employed, the most important thing is to carry out task-based classroom activities, focus on tasks, and reasonably plan teaching procedure. In view of this, the 
quality of task design is an important index for measuring the quality of course. In the process of task fulfillment, small group teaching is an important method. In actual small group teaching process, however, problem of irrational distribution occurs frequently, and it happens that many students cannot involve in the process of task fulfillment ${ }^{[5]}$. Thus, ideal results of task-based language teaching will not be achieved. Hence, teachers should give full consideration to students' situations in the process of grouping, to refine task design to cover all students. Reasonable distribution of tasks is important to delivering lectures by grouping students. Besides, data collection and lecture deliverer arrangement should be well made. Only in this way, it can be ensured that students can really take part in task-based language teaching.

According to the standard contents of English teaching, task-based teaching is explicitly advocated, but no requirement is made that teachers must adopt task-based teaching mode. Thus, teachers have their choices. There are not many methods for teachers to train students' language ability, and teachers should improve their own language ability. Therefore, the most important thing is to make rational use of experience and methods related to task-based language teaching, to realize constructive combination of teaching with learning. Most importantly, teachers should fully and deeply learn about the concept and connotation of task-based language teaching, and master the theoretical basis and teaching background of this method. On this basis, what situations are suitable for this teaching method should be considered. English teaching involves many contents, and each unit contains contents that students must master, review and consolidate. Therefore, practice lessons should be carried out. It is unnecessary to employ task-based teaching method in all courses. On the contrary, task-based language teaching should be correctly realized. It is a kind of idea and method of teaching, and not an indispensible step in teaching procedure. Besides, task-based teaching may be suitable for every lesson, especially for lessons in which new knowledge is imparted, for which reasonable discuss activities should be designed before dialogue and text learning. In addition, students should be encouraged to have activities, and find corresponding information and contents in dialogue and text contents.

\section{Conclusion}

To sum up, task-based language teaching method plays an important role in English teaching of application-oriented universities. Hence, in English teaching process, teachers should properly use task-based language teaching method, explore new teaching approaches, mobilize the initiative of students, and combine it with traditional teaching methods, to promote English teaching of application-oriented universities to further develop, output more excellent application-oriented talents, and make greater contributions to international communication.

\section{Reference}

[1] Wang Yuhong, Li Chao, Wei Lai, et al. Discussions on the Application of Task-based Language Teaching Method in English Teaching of Application-oriented Universities, Journal of Juamjusi Education Institute, 2016(1): 382, 384.

[2] Jin Xin. Discussions on the Application of Task-based Language Teaching Method in English Teaching of Application-oriented Universities, English on Campus (Middle Ten-day), 2015(9): 23.

[3] Han Song. Brief Analysis on the Application of Task-based Language Teaching Method in English Teaching of Application-oriented Universities, New Campus (Study), 2013(2): 27.

[4] Zhao Yanting. Brief Discussion on Task-based Language Teaching Method in English Teaching, Hua Zhang, 2012 (28): 217, 219.

[5] Xu Lisu. Realization of Task-based Language Teaching Method in English Teaching, Liberal Arts Fans: Education and Teaching Edition, 2011(6): 82-82. 
